\title{
KLASIFIKASI BEBERAPA SUMBER BAHAN ORGANIK DAN OPTIMALISASI PEMANFAATANNYA SEBAGAI BIOCHAR Sismiyanti ${ }^{1)}$, Hermansah ${ }^{2)}$, dan Yulnafatmawita ${ }^{2)}$ \\ 1)Program MagisterIlmu Tanah Fakultas Pertanian Universitas Andalas \\ 2) Jurusan Tanah Fakultas Pertanian Universitas Andalas \\ Kampus Limau Manis Padang 25163 Telp.(0751) 71686, Fax (0751) 71691 \\ email : bundaichin33@gmail.com
}

\begin{abstract}
Abstrak
Optimalisasi pemanfaatan bahan organik akan dapat dilakukan dengan mengetahui kualitas bahan organik tersebut. Kualitas bahan organik tidak hanya ditentukan oleh kandungan hara, namun juga kecepatan pelapukannya yang dilihat dari kandungan lignin, nisbah $\mathrm{C} / \mathrm{N}, \mathrm{C} / \mathrm{P}$, dan $\mathrm{C} / \mathrm{S}$. Pengujian terhadap 24 jenis sumber bahan organik di Kota Padang ini telah dilakukan pada bulan November 2016-April 2017 di laboratorium kimia tanah Fakultas Pertanian Universitas Andalas. Penelitian ini bertujuan untuk mengelompokkan bahan organik berdasarkan kandungan haranya, menentukan bahan organik yang dapat dimanfaatkan sebagai sumber biochar, dan mengkaji karakteristik dari biochar yang dihasilkan. Parameter analisis bahan organik meliputi kadar air, Ctotal, N-total, P-total, K-total, C/N, C/S, C/P, dan kadar lignin. Parameter analisis biochar meliputi kadar air, kandungan N-total, C-total, P-total, K-total, S-total C/N, dan kadar abu. Dua puluh empat (24) sumber bahan organik yang tersedia, dapat disimpulkan bahwa berdasarkan kandungan haranya bahan organik ini diklasifikasikan menjadi 2 yaitu : a) bahan organik berkualitas tinggi, yang terdiri dari: tithonia, krinyuh, gamal, kiambang, widelia, paku resam, azola, enceng gondok, alang-alang, jerami kacang tanah, jerami kedele, jerami jagung, kulit kakao, pupuk kandang ayam, pupuk kandang sapi, dan kulit jengkol, dan b) bahan organik berkualitas rendah yang dinyatakan berdasarkan kadar lignin, $\mathrm{C} / \mathrm{N}, \mathrm{C} / \mathrm{P}$ dan $\mathrm{C} / \mathrm{S}$ yang tinggi, yang terdiri dari : jerami padi, sekam padi, pelepah kelapa sawit, tongkol jagung, tandan kosong kelapa sawit, ampas tebu, ampas kelapa sawit, dan serbuk gergaji. Bahan organik berkualitas rendah yang dioptimalkan untuk dimanfaatkan sebagai bahan biochar adalah jerami padi, sekam padi, dan tandan kosong kelapa sawit, dengan karakteristik kimia biochar yang dihasilkan memiliki C-total (28,86\%), N-total (1,27\%), P-total (0,28\%), K-total (0,76\%), S-total (0,21\%), kadar abu $(25,42 \%)$, $\mathrm{C} / \mathrm{N}(22,72), \mathrm{C} / \mathrm{P}(103,07)$, dan C/S $(137,43)$.
\end{abstract}

Kata kunci : bahan organik, biochar.

(C) 2018 Sismiyanti Sismiyanti, Hermansah Hermansah, Yulnafatmawita Yulnafatmawita

\section{PENDAHULUAN}

Masalah degradasi tanah sangat banyak terjadi belakangan ini, yang akhirnya mempengaruhi produktivitas suatu lahan. Pada tanah-tanah tererosi, hilangnya lapisan tanah atas menyebabkan kehilangan bahan organik tanah yang lebih besar. Hasil penelitian Liu et al. (2010) di Cina menunjukkan bahwa ratarata tingkat penurunan tahunan bahan organik tanah adalah $0,5 \%$, sedangkan tingkat penurunan rata-rata tahunan bahan organik tanah pada tanah-tanah yang tererosi berat adalah $1,35 \%$.
Di lain pihak, Indonesia memiliki sumber dan pupuk organik yang melimpah yang belum dimanfaatkan secara optimal. Peranan bahan organik sangat besar dalam meningkatkan kesuburan tanah, dan akan menentukan produktivitas tanah (Atmojo, 2003). Jenis bahan organik yang bisa dimanfaatkan kembali ke tanah sangatlah banyak, baik produk sampah maupun hasil dari perusahaan pertanian, pengolahan makanan, sampah kota, maupun industri. Umumnya, bahan organik yang tersedia dan dimanfaatkan meliputi : limbah pertanian, limbah kota, limbah organik dari pengolahan makanan, 
limbah organik dari pabrik kertas dan kayu industri, dan sisa makanan konsumen (Cooperband, 2002) ; sisa dan kotoran hewan (pupuk kandang), sisa tanaman, pupuk hijau, sampah kota, limbah industri, kompos (Atmojo, 2003), dan residu tanaman atau bahan hijauan tanaman (Yulnafatmawita et al. 2008; 2010). Semuanya sangat berpotensi untuk diolah menjadi bahan yang bermanfaat untuk meningkatkan kesuburan tanah secara alami sebagai pupuk organik, karena mengandung hara yang cukup tinggi.

Selain itu, masih perlu dilakukan klasifikasi sumber bahan organik tersebut, tidak hanya kandungan hara tetapi juga kualitas dan kecepatan pelapukannya yang dilihat dari $\mathrm{C} / \mathrm{N}, \mathrm{C} / \mathrm{P}, \mathrm{C} / \mathrm{S}$, dan kandungan lignin. Atmojo (2003) menyimpulkan, nisbah $\mathrm{C} / \mathrm{N}, \mathrm{C} / \mathrm{P}$ dan $\mathrm{C} / \mathrm{S}$ akan menentukan proses mineralisasi dan immobilisasi N, P dan S dari bahan organik tersebut, sehingga akan mempengaruhi sumbangan hara dari bahan organik ke dalam tanah. Selanjutnya Yuwono (2008) juga memperkuat bahwa $\mathrm{C} / \mathrm{N}$ dan lignin akan mempengaruhi kualitas bahan organik. Kualitas bahan organik akan menentukan kecepatan mineralisasi residu tanaman yang merupakan faktor yang kritikal dalam mempengaruhi dekomposisi dan pelepasan unsur hara.

Kecepatan dekomposisi bahan organikjuga ditentukan oleh kandungan lignin dan nisbah $\mathrm{C} / \mathrm{N}$. secara garis besar membagi bahan tanaman berdasarkan kualitas, yakni tergolong berkualitas tinggi bila mengandung $\mathrm{N}$ paling sedikit 2,5\%, kandungan lignin dan polifenol masing-masing $<15 \%$ dan $<4 \%$. Bila diaplikasikan ke dalam tanah (sebagai pupuk hijau), pelepasan $\mathrm{N}$ benar-benar dapat terjadi (net release of nitrogen) jika kandungan lignin dan polifenol masing-masing $<15 \%$ dan $<4 \%$. Di sisi lain, bahan tanaman yang mengandung $\mathrm{N}<2,5 \%$ tergolong berkualitas rendah, demikian juga halnya bahan-bahan tanaman yang menyebabkan terjadinya imobilisasi $\mathrm{N}$ selama terjadinya proses dekomposisi, yakni tanaman yang mengandung lignin dan polifenol tinggi (Palm et al., 2001). Oleh karena itu, bahan organik yang memiliki kandungan lignin dan nisbah $\mathrm{C} / \mathrm{N}$ yang tinggi dapat dimanfaatkan dan ditambahkan ke tanah dalam bentuk biochar.

Biochar merupakan substansi arang kayu yang berpori (porous), sering juga disebut charcoal atau agri-char. Pemanfataan bahan organik dalam bentuk biochar diketahui juga dapat memperbaiki kesuburan kimia, fisika, dan biologi tanah. Biochar mampu memperbaiki tanah melalui kemampuannya meningkatkan $\mathrm{pH}$, meretensi hara, dan nutrisi lebih tersedia bagi tanaman (Maftu'ah dan Nursyamsi, 2015; Santi dan Goenadi, 2012), tidak mengganggu keseimbangan karbonnitrogen, meretensi air (Santi dan Goenadi, 2012) menyediakan habitat yang baik bagi mikroba tanah meningkatkan aktivitas biota dalam tanah serta mengurangi pencemaran (Maftu'ah dan Nursyamsi, 2015; Santi dan Goenadi, 2012).

Bahan organik yang dapat dimanfaatkan sebagai bahan baku biochar juga beragam, dan telah banyak dikemukakan dalam penelitian. Diantaranya yaitu jerami padi (Maftu'ah dan Nursyamsi, 2015), cangkang kelapa sawit (Santi dan Goenadi, 2012), jerami jagung dan tandan kosong kelapa sawit (Maftu'ah dan Nursyamsi, 2015), serbuk gergaji (Komarayati et al. 2012), dan sekam padi (Maftu'ah dan Nursyamsi, 2015; Saputra et al. 2016).

Dengan demikian, akan semakin menguatkan bahwa bahan organik memiliki peran yang sangat penting dalam peningkatan kesuburan tanah. Oleh karena itu, perlu dilakukan penelitian sebagai upaya dalam mengklasifikasikan bahan organik berdasarkan kandungan unsur hara dan kecepatan dekomposisinya sebagai dasar dalam menentukan kualitas bahan organik dan cara pengelolaannya untuk ditambahkan ke lahan pertanian.

\section{BAHAN DAN METODA}

Penelitian ini diawali dengan analisis 24 jenis bahan organik, yang terdiri dari 3 kelompok. Dua puluh empat bahan organik berdasarkan kelompoknya adalah sebagai berikut : 1) kelompok bahan organik segar 
(alang-alang), azola, enceng gondok, gamal, kiambang, krinyuh, paku resam, tithonia, dan widelia); 2) kelompok sisa panen (jerami jagung, jerami kacang tanah, jerami kedele, jerami padi, kulit kakao, dan pelepah kelapa sawit); 3) limbah industripertanian/perkebunan (ampas kelasa sawit, ampas tebu, kulit jengkol, pupuk kandang ayam, pupuk kandang sapi, sekam padi, serbuk gergaji, dan tandan kosong kelapa sawit.
Analisis bahan organik meliputi kadar air, C-total dengan metode pengabuan kering, $\mathrm{N}$-total dengan metode destruksi basah, P-total dengan metode destruksi basah, K-total, $\mathrm{C} / \mathrm{N}$, $\mathrm{C} / \mathrm{S}, \mathrm{C} / \mathrm{P}$, dan kadar lignin. Selanjutnya dilakukan klasifikasi pada bahan organik tersebut berdasarkan pada kandungan hara dan pelapukannya, dengan parameter pengelompokkan disajikan pada Tabel 1.

Tabel 1. Parameter yang digunakan dalam mengelompokkan bahan organik

\begin{tabular}{lcc}
\hline \multirow{2}{*}{ Parameter klasifikasi bahan organik } & \multicolumn{2}{c}{ Nilai } \\
\cline { 2 - 3 } & Kualitas tinggi & Kualitas rendah \\
\hline Kandungan N (\%)* & $>1,9$ & $<1,9$ \\
Kandungan P (\%)* & $>0,25$ & $<0,25$ \\
Kandungan Lignin $(\%)^{*}$ & $<15$ & $>15$ \\
Nisbah C/N ** & $<25$ & $>30$ \\
Nisbah C/P** & $<200$ & $>200$ \\
Nisbah C/S** & $<200$ & $>200$ \\
\hline
\end{tabular}

*) sumber: Hairiah et al. (2000)

**) sumber : Atmojo (2003)

Selanjutnya tiga bahan organik dari kelompok yang sulit terdekomposisi dan berkualitas rendah diolah menjadi biochar. Pemilihan tiga bahan organik tersebut berdasarkan potensinya (kandungan hara dan tersedia dalam jumlah yang banyak). Bahan baku biochar tersebut adalah jerami padi, sekam padi, dan tandan kosong kelapa sawit.

Selanjutnya 3 jenis bahan organik sebagai bahan baku biochar diambil sebanyak $5 \mathrm{~kg}$ (setara berat kering) dengan perbandingan 1:1:1. Jerami padi, dan tandan kosong kelapa sawit dicacah kecil-kecil dengan ukuran $\pm 3-4 \mathrm{~cm}$. Ketiga bahan dicampur dan dimasukkan ke dalam sebuah tong dengan ukuran tinggi $60 \mathrm{~cm}$ dan diameter $40 \mathrm{~cm}$. Kemudian dibakar, dan setelah api menyala tong tersebut ditutup rapat tanpa ada udara yang masuk. Hal ini bertujuan agar bahan organik yang dibakar tidak sampai menjadi abu. 5 menit kemudian setelah semua bahan terbakar, penutup tong dibuka dan dilakukan pengadukan untuk memastikan semua bahan sudah terbakar. Selanjutnya bahan yang sudah menjadi arang (biochar) dikeluarkan dari tong. Proses pembakaran terus dilakukan sampai semua bahan habis dan kebutuhan biochar tercukupi.

Analisis biochar meliputi kadar air, kandungan $\mathrm{N}$-total dengan metode destruksi basah, C-total dengan metode pengabuan kering, P-total, K-total, dan S-total dengan metode destruksi basah, $\mathrm{C} / \mathrm{N}$, dan kadar abu .

\section{HASIL DAN PEMBAHASAN}

Berdasarkan hasil analisis 24 jenis sumber bahan organik, diketahui total karbon tanaman (C-total) berkisar 13,32-55,96\%. Total karbon pada bahan organik yang berasal dari limbah industri pertanian/perkebunan cenderung lebih tinggi dibandingkan dengan bahan organik segar. Tinggi rendahnya total karbon akan mempengaruhi laju dekomposisi bahan organik. Semakin tinggi kandungan Ctotal, maka semakin lama proses dekomposisi bahan organik tersebut. Sebaliknya, pada bahan organik dengan kandungan C-total yang lebih rendah akan memungkinkan proses dekomposisi berlangsung lebih cepat.

Dibandingkan dengan kelompok sisa panen dan limbah industri pertanian/perkebunan, bahan organik segar 
memiliki total $\mathrm{N}$ yang relatif lebih tinggi, yaitu berkisar 1,61-4,5\% (Tabel 2). Tabel 2 menjelaskan bahwa total $\mathrm{N}$ pada berbagai sumber bahan organik berkisar 0,04-4,59\%. Sementara total karbon tanaman berkisar 13,32-55,96\%, dimana bahan organik limbah industri pertanian/perkebunan cenderung lebih tinggi.

Kandungan hara N, P dan $\mathrm{S}$ sangat menentukan kualitas bahan organik. Nisbah $\mathrm{C} / \mathrm{N}, \mathrm{C} / \mathrm{P}$, dan $\mathrm{C} / \mathrm{S}$ serta kandungan lignin juga menjadi faktor penentu dalam memilih bahan organik. Yuwono (2008) menyatakan, salah satu faktor kualitas yang baik untuk menjelaskan kecepatan dekomposisi adalah kandungan lignin. Berdasarkan hasil penelitiannya, kandungan lignin mempunyai nilai koefisien determinasi $\left(\mathrm{R}^{2}\right)$ sebesar 0,791 .
Hal ini berarti bahwa 79,1\% dari dekomposisi bahan organik dipengaruhi oleh nilai kandungan lignin. Palm et al. (2001) mengkategorikan bahan tanaman yang cepat terdekomposisi sebagai sumber bahan organik bila kandungan lignin $<15 \%$.

Kecepatan dekomposisi bahan organik ditentukan oleh jenis bahan organiknya. Jumlah lignin dan nisbah $\mathrm{C} / \mathrm{N}$ merupakan dua faktor yang berkorelasi positif terhadap kecepatan dekomposisi bahan organik. Menurut Pardono (2011), bahan organik yang mempunyai nisbah $\mathrm{C} / \mathrm{N}$ rendah dan kandungan lignin yang rendah akan cepat terdekomposisi. Sebaliknya, bahan organik yang memiliki nisbah $\mathrm{C} / \mathrm{N}$ dan lignin yang tinggi akan sulit terdekomposisi.

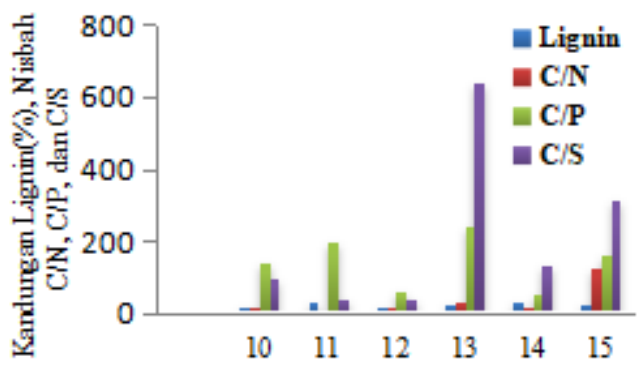

Jenis bahan organik dari sisa panen

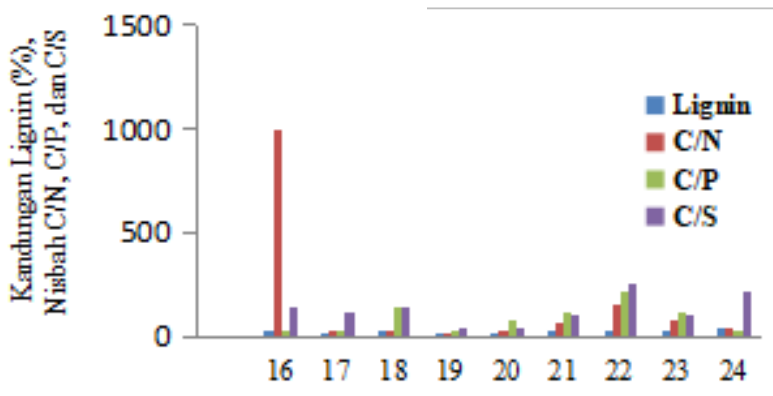

Jenis bahan organik dari limbah...

Keterangan : 1) alang-alang, 2) azola, 3) enceng godok, 4) gamal, 5) kiambang, 6) krinyuh, paku resam, 8) tithonia, 9) widelia, 10) jerami jagung, 11) jerami kacang tanah, 12) jerami kedele, 13) jerami padi, 14) kulit kakao, 15) pelepah kelapa sawit,

16) ampas kelapa sawit, 17) ampas tebu, 18) kulit jengkol, 19) pupuk kandang ayam, 20) pupuk kandang sapi, 21) sekam padi, 22) serbuk gergaji, 23) tandan kosong kelapa sawit, 24) tongkol jagung

Gambar 1. Nisbah C/N, C/P dan C/S dan kandungan lignin pada beberapa bahan organik kelompok bahan organik segar, sisa panen, dan limbah industri pertanian/perkebunan 
Tabel 2. Kandungan hara (C, N, P, K, dan S), lignin, C/N, C/P, dan C/S pada beberapa jenis bahan organik

\begin{tabular}{|c|c|c|c|c|c|c|c|c|c|}
\hline Bahan Organik & $\mathrm{C}(\%)$ & $\mathrm{N}(\%)$ & $\mathrm{P}(\%)$ & $\mathrm{K}(\%)$ & $\mathrm{S}(\%)$ & Lignin (\%) & $\mathrm{C} / \mathrm{N}$ & $\mathrm{C} / \mathrm{P}$ & $\mathrm{C} / \mathrm{S}$ \\
\hline \multicolumn{10}{|l|}{ Bahan Organik Segar } \\
\hline Alang-alang & 23,74 & 2,57 & $\mathbf{0 , 5 5}$ & 1,58 & 0,63 & 31,29 & 9,24 & 37,68 & 37,68 \\
\hline Azola & 28,53 & 2,76 & 0,23 & 1,54 & 0,57 & 23,59 & 10,34 & 50,05 & 50,05 \\
\hline Enceng Gondok & 30,90 & 1,61 & 0,31 & 3,81 & 1,66 & 28,20 & 19,19 & 18,61 & 18,61 \\
\hline Gamal & 25,00 & 3,17 & 0,31 & 0,77 & 0,91 & 15,80 & 7,89 & 27,47 & 27,47 \\
\hline Kiambang & 39,90 & 4,50 & 0,50 & 2,90 & 0,62 & 17,00 & 8,87 & 64,35 & 64,35 \\
\hline Krinyuh & 34,40 & 2,42 & 0,26 & 1,60 & 1,04 & 13,50 & 14,21 & 33,08 & 33,08 \\
\hline Paku resam & 17,00 & 2,26 & 1,14 & 1,90 & 0,45 & 20,21 & 7,52 & 37,78 & 37,78 \\
\hline Tithonia & 18,50 & 3,29 & 0,39 & 3,45 & 0,95 & 11,37 & 5,62 & 19,47 & 19,47 \\
\hline Widelia & 21,50 & 2,17 & 0,44 & 2,01 & 0,72 & 18,61 & 9,91 & 29,86 & 29,86 \\
\hline \multicolumn{10}{|l|}{ Sisa Panen } \\
\hline Jerami jagung & 40,90 & 2,20 & 0,30 & 2,69 & 0,44 & 19,30 & 18,59 & 136,33 & 92,95 \\
\hline Jerami kacang tanah & 48,51 & 4,59 & 0,25 & 2,03 & 1,17 & 30,00 & 10,57 & 194,04 & 41,46 \\
\hline Jerami kedele & 38,00 & 2,84 & 0,67 & 2,41 & 1,09 & 20,06 & 13,38 & 56,72 & 34,86 \\
\hline Jerami padi & 51,11 & 1,86 & 0,21 & 5,25 & 0,08 & 22,25 & 27,48 & 243,38 & 638,88 \\
\hline Kulit kakao & 27,21 & 1,81 & 0,52 & 1,36 & 0,21 & 30,45 & 15,03 & 52,33 & 129,57 \\
\hline Pelepah kelapa sawit & 55,96 & 0,45 & 0,35 & 5,88 & 0,18 & 25,45 & 124,36 & 159,89 & 310,89 \\
\hline \multicolumn{10}{|c|}{ Limbah Industri Pertanian/Perkebunan } \\
\hline Ampas kelapa sawit & 39,68 & 0,04 & 1,40 & 9,20 & 0,28 & 23,73 & 992,00 & 28,34 & 141,71 \\
\hline Ampas tebu & 13,32 & 0,42 & 1,20 & 0,96 & 0,12 & 18,00 & 31,71 & 29,60 & 111,00 \\
\hline Kulit jengkol & 44,51 & 1,80 & 1,06 & 2,11 & 0,32 & 21,17 & 24,73 & 139,09 & 139,09 \\
\hline Pupuk kandang ayam & 26,60 & $\mathbf{3 , 8 0}$ & 0,50 & 2,85 & 0,62 & 12,93 & 7,00 & 22,17 & 42,90 \\
\hline Pupuk kandang sapi & 20,10 & 1,62 & 0,45 & 0,29 & 0,55 & 14,71 & 12,41 & 71,79 & 36,55 \\
\hline Sekam padi & 49,07 & 0,84 & 0,32 & 3,25 & 0,46 & 32,69 & 58,42 & 119,68 & 106,67 \\
\hline Serbuk gergaji & 14,85 & 0,10 & 0,28 & 0,62 & 0,06 & 22,65 & 148,50 & 212,14 & 247,50 \\
\hline Tandan kosong kelapa sawit & 55,49 & 0,70 & 0,07 & 7,30 & 0,54 & 25,60 & 79,27 & 110,98 & 102,76 \\
\hline Tongkol jagung & 32,75 & 0,89 & 0,41 & 1,17 & 0,15 & $\mathbf{3 3 , 3 0}$ & 36,80 & 30,90 & 218,33 \\
\hline
\end{tabular}


Berdasarkan Tabel 2, diketahui bahwa tithonia merupakan bahan organik yang memiliki nisbah $\mathrm{C} / \mathrm{N}$ paling rendah, yaitu $5,62 \%$. Berdasarkan urutan $\mathrm{C} / \mathrm{N}$ yang paling rendah sampai yang lebih tinggi pada bahan organik segar yang digunakan yaitu : tithonia $<$ paku resam $<$ gamal $<$ kiambang $<$ alang-alang $<$ widelia $<$ azolla $<$ krinyuh. Selain itu, rasio $\mathrm{C} / \mathrm{N}$ dapat digunakan untuk memprediksi kualitas bahan organik. Bahan organik akan termineralisasi jika nisbah $\mathrm{C} / \mathrm{N}$ di bawah nilai kritis 25-30. Sebaliknya, apabila $\mathrm{C} / \mathrm{N}$ di atas 30 maka akan terjadi immobilisasi N (Stevenson, 1982). Sementara Supriyadi (2008) melaporkan, substrat organik dengan rasio $\mathrm{C} / \mathrm{N}$ sempit $(<25)$ menyebabkan dekomposisi berjalan cepat, sebaliknya pada bahan dengan $\mathrm{C} / \mathrm{N}$ lebar (>25) maka mendorong terjadinya immobilisasi.

Tabel 2 juga menunjukkan bahwa kisaran $\mathrm{C} / \mathrm{N}$ bahan organik segar

$20 \%$. Artinya, bahan organik segar akan membutuhkan waktu yang lebih singkat dalam proses dekomposisi dan mineralisasi $\mathrm{N}$ dibandingkan dengan lainnya. Pada umumnya bahan organik segar memiliki potensi lebih cepat terdekomposisi.

Nisbah $\mathrm{C} / \mathrm{N}$ bahan organik yang berasal dari sisa panen dan limbah industri pertanian/perkebunan jauh lebih tinggi dibandingkan dengan bahan organik segar (Gambar 1). Begitu juga dengan kandungan lignin, nisbah $\mathrm{C} / \mathrm{P}$ dan nisbah $\mathrm{C} / \mathrm{S}$. Variasi kandungan lignin, Nisbah $\mathrm{C} / \mathrm{P}$, dan $\mathrm{C} / \mathrm{S}$ pada bahan organik yang berasal dari sisa panen dan limbah industri pertanian/perkebunan memiliki range yang lebih besar dibandingkan dengan bahan organik segar. Faktor ini yang mungkin memperkuat bahwa bahan organik segar lebih mudah terdekomposisi. Hal ini menggambarkan bahwa diperlukan pengolahan sebagai upaya mengoptimalkan peran dan potensi bahan organik dari kelompok sisa panen dan juga limbah industri pertanian/perkebunan.

Tabel 3. Klasifikasi beberapa bahan organik berdasarkan kandungan $\mathrm{N}, \mathrm{P}$, lignin, nisbah $\mathrm{C} / \mathrm{N}$, nisbah $\mathrm{C} / \mathrm{P}$, dan nisbah $\mathrm{C} / \mathrm{S}$ Bahan Organik Kualitas Tinggi Bahan Organik Kualitas Rendah

\begin{tabular}{ll}
\hline \multicolumn{1}{c}{ Bahan Organik Kualitas Tinggi } & \multicolumn{1}{c}{ Bahan Organik Kualitas Rendah } \\
\hline Bahan Organik Segar & \\
Tithonia & \\
Krinyuh & \\
Gamal & \\
Kiambang & \\
Widelia & \\
Paku resam & \\
Azola & \\
Enceng gondok & \\
Alang-alang & \\
Sisa Panen & \\
Jerami kacang tanah & Jerami padi \\
Jerami kedele & Sekam padi \\
Jerami jagung & Pelepah kelapa sawit \\
Kulit kakao & \\
Limbah Industri Pertanian/Perkebunan & \\
Pupuk kandang ayam & Tongkol jagung \\
Pupuk kandang sapi & Tandan kosong kelapa sawit \\
Kulit jengkol & Ampas tebu \\
& Ampas kelapa sawit \\
& Serbuk gergaji \\
\hline
\end{tabular}


Pemanfaatan Bahan Organik dalam Bentuk Biochar

Berdasarkan Tabel 3, dapat dinyatakan bahwa bahan organik yang berasal dari kelompok bahan organik segar tergolong pada bahan organik berkualitas tinggi. Artinya, bahan organik segar ini dapat langsung ditambahkan ke dalam tanah, baik langsung (pupuk hijau) ataupun dikomposkan. Sementara itu, bahan organik yang berasal dari sisa panen dan limbah industri pertanian/perkebunan terdapat bahan organik yang berkualitas rendah, diantaranya jerami padi, sekam padi, dan tandan kosong kelapa sawit. Dalam pemanfaatannya, bahan organik berkualitas rendah ini perlu diolah terlebih dahulu, misalnya dijadikan kompos atau diaplikasikan dalam bentuk biochar.

Pemanfaatan bahan organik yang sukar terdekomposisi menjadi biochar merupakan salah satu alternatif dalam memaksimalkan peran bahan organik. Biochar merupakan bahan alternatif untuk perbaikan kesuburan tanah sekaligus untuk perbaikan lingkungan yang murah, berkelanjutan, dan ramah lingkungan. Biochar dapat memperbaiki sifat kimia, fisik, dan biologi tanah. Maftu'ah dan Nursyamsi (2015) melaporkan bahwa biochar bisa dibuat dari sekam padi, jerami jagung, jerami padi, kalakai, karamunting, galam, bambu, bungkil sawit daun sawit, pelepah sawit, tandan sawit, tempurung kelapa dan purun tikus.

Dalam penelitian ini bahan baku biochar yang digunakan adalah jerami padi, sekam padi, dan tandan kosong kelapa sawit. Berdasarkan analisis yang dilakukan, didapatkan karakteristik kimia biochar. Karakteristik biochar dapat dilihat pada Tabel 4.

Tabel 4. Karakteristik kimia biochar (jerami padi, sekam padi, dan tandan kosong kelapa sawit)

\begin{tabular}{lr}
\hline Jenis Analisis & Nilai \\
\hline C-organik (\%) & 28,86 \\
N-total (\%) & 1,27 \\
P-total (\%) & 0,28 \\
K-total (\%) & 0,76 \\
S-total (\%) & 0,21 \\
Abu (\%) & 25,42 \\
C/N & 22,72 \\
C/P & 103,07 \\
C/S & 137,43 \\
\hline
\end{tabular}

Karakteristik kimia biochar tergantung pada jenis bahan baku yang digunakan. Berdasarkan Tabel 4, di dalam biochar terdapat C-organik 28,86\% dan $\mathrm{C} / \mathrm{N}$ 22,72. Apabila dibandingkan dengan rata-rata $\mathrm{C} / \mathrm{N}$ bahan baku (Tabel 2), C/N biochar menjadi lebih rendah. Begitu juga dengan rasio $\mathrm{C} / \mathrm{P}$ dan $\mathrm{C} / \mathrm{S}$ pada biochar lebih rendah dibandingkan dengan bahan baku. Lebih rendahnya rasio $\mathrm{C} / \mathrm{N}, \mathrm{C} / \mathrm{P}$ dan $\mathrm{C} / \mathrm{S}$ tersebut menandakan bahwa ada kemungkinan lebih cepatnya proses mineralisasi pada biochar. Penambahan biochar ke dalam tanah diharapkan dapat meningkatkan kualitas tanah. Mawardiana et al. (2013) menyatakan, berdasarkan hasil penelitiannya dilaporkan bahwa pemberian biochar ke tanah berpotensi meningkatkan kadar C-organik tanah, retensi air, dan unsur hara di dalam tanah.

\section{KESIMPULAN}

Dua puluh empat (24) sumber bahan organik yang tersedia, dapat disimpulkan bahwa berdasarkan kandungan haranya bahan organik ini diklasifikasikan menjadi 2 yaitu : a) bahan organik berkualitas tinggi, yang terdiri dari: tithonia, krinyuh, gamal, kiambang, widelia, paku resam, azola, enceng 
gondok, alang-alang, jerami kacang tanah, jerami kedele, jerami jagung, kulit kakao, pupuk kandang ayam, pupuk kandang sapi, dan kulit jengkol, dan b) bahan organik berkualitas rendah yang dinyatakan berdasarkan kadar lignin, $\mathrm{C} / \mathrm{N}, \mathrm{C} / \mathrm{P}$ dan $\mathrm{C} / \mathrm{S}$ yang tinggi, yang terdiri dari : jerami padi, sekam padi, pelepah kelapa sawit, tongkol jagung, tandan kosong kelapa sawit, ampas tebu, ampas kelapa sawit, dan serbuk gergaji. Bahan organik berkualitas rendah yang dioptimalkan untuk dimanfaatkan sebagai bahan biochar adalah jerami padi, sekam padi, dan tandan kosong kelapa sawit, dengan karakteristik kimia biochar yang dihasilkan memiliki C-total $(28,86 \%)$, N-total (1,27\%), P-total $(0,28 \%)$, K-total $(0,76 \%)$, Stotal $(0,21 \%)$, kadar abu $(25,42 \%), \mathrm{C} / \mathrm{N}(22,72)$, C/P $(103,07)$, dan C/S $(137,43)$.

\section{DAFTAR PUSTAKA}

Atmojo, S. W. 2003. Peranan Bahan Organik terhadap Kesuburan Tanah dan Upaya Pengelolaannya. [Pidato Pengukuhan]. Surakarta. Sebelas Maret University Press. 35 hal. http://suntoro.staff.uns.ac.id [diakses 23 Mei 2017].

Cooperband, L. 2002. Building Soil Organic Matter with Organic Amendments. Center for Integrated Agricultural Systems. University of WisconsinMadison. pp 16.

Hairiah, K., Widianto, S.R. Utami., D. Suprayogo, Sunaryo., S.M. Sitompul., B. Lusiana., R. Mulia., M.V. Noorwijk., dan G. Cadish. 2000. Pengelolaan Tanah Masam Secara Biologi; Refleksi Pengalaman dari Lampung Utara. International Centre For Research in Agroforestry. Bogor.

Komarayati, S., Gusmailina., dan G. Pari. 2012. Arang dan Cuka Kayu: Produk Hasil Hutan Bukan Kayu untuk Meningkatkan Pertumbuhan Tanaman dan Serapan Hara. Penelitian Hasil Hutan 31 (1): 49-62.
Liu, X. B., X.Y. Zhang,. Y.X Wang,. Y.Y Sui,. S.L. Zhang,. S.J. Herbert., dan G. Ding. 2010. Soil Degradation: a Problem Threateningthe Sustainable Developmentof Agriculture in Northeast China. Plant Soil Environ 56 (2): 87-97.

Maftu'ah, E. dan D. Nursyamsi. 2015. Potensi berbagai Bahan Organik Rawa sebagai Sumber Biochar. Seminar Nasional Masyarakat Biodiv Indonesia. 1(4) : 776-781.

Mawardiana, Sufardi., dan E. Husen. 2013. Pengaruh Residu Biochar dan Pemupukan NPK terhadap Sifat Kimia Tanah dan Pertumbuhan serta Hasil Tanaman Padi Musim Ketiga. Konservasi Sumber Daya Lahan I(1): 16-23.

Palm, C.A., C.N. Gachengo., R.J. Delve., G. Candisch And K.E. Giller. 2001. Organic input for soil fertility management and tropical agroecosystem: Aplication of an organic resource data base. Agriculture, Ecosystem and Environment 83: 27-42.

Pardono. 2011. Potensi Chromolaena odorata dan Tithonia diversifolia sebagai Sumber Nutrisi Bagi Tanaman Berdasarkan Kecepatan Dekomposisinya (Studi Kasus di Desa Sobokerto Boyolali Jawa Tengah). Agrivor 4 (2):80-85.

Santi, L. P dan D. H. Goenadi. 2012. Pemanfataan Biochar asal Cangkang Kelapa Sawit sebagai Bahan Pembawa Mikroba Pemantap Agregat. Buana Sains 12 (1): 7-14.

Saputra, A. R. T., L. Rahmawati., D. Budianta., dan S. J. Priatna. 2016. Serapan Nitrogen pada Pertumbuhan Padi (Oriza Sativa L.) dengan Pemberian Biochar di Lahan Rawa Lebak. 
Prosiding Seminar Nasional Lahan Suboptimal. Palembang.

Stevenson, F. T. 1982. Humus Chemistry. John Wiley and Sons, Newyork.

Supriyadi, S. 2008. Kandungan Bahan Organik sebagai Dasar Pengelolaan Tanah di Lahan Kering Madura. Embriyo 5 (2): 176-183.

Yulnafatmawita, Adrinal, A. F. Daulay. 2008. Pengaruh Pemberian beberapa Jenis Bahan Organik Terhadap Stabilitas
Agregat Tanah Ultisol Limau Manis. Solum 5(1): 7-13.

Yulnafatmawita., A. Saidi., Gusnidar., Adrinal., dan Suyoko. 2010. Peranan Bahan Hijauan Tanaman dalam Peningkatan Bahan Organik dan Stabilitas Aggregat Tanah Ultisol Limau Manis yang Ditanami Jagung (Zea mays, L.). Solum 7 (1): 37-48.

Yuwono, M. 2008. Dekomposisi dan Mineralisasi beberapa Macam Bahan Organik. Agronomi 12 (1): 1-8. 